\title{
OD OBRAZU DO PODOBIEŃSTWA BOŻEGO. DYNAMICZNA KONCEPCJA ANTROPOLOGII TEOLOGICZNEJ W II-III WIEKU (Stanowisko Ireneusza i Orygenesa)
}

Jak przypomina w wydanym ostatnio podręczniku Antropologii teologicz$n e j$ Georg Langemeyer ${ }^{1}$, wyjściowy tekst biblijny antropologii teologicznej stanowią słowa Księgi Rodzaju o stworzeniu człowieka na obraz i podobieństwo Boże (Rdz 1, 26-27). Kierują one wypowiedzi antropologii i teologii na zakorzenienie i dopełnienie człowieka w Bogu. Człowiek został powołany do istnienia na obraz Boga. Dążenie człowieka do zbawienia, które można określić charakterystycznym dla wielu teologów doby patrystycznej obrazowym pojęciem „drogi do Boga”, jest natomiast ciągłym upodabnianiem się do Niego.

Problem rozumienia obrazu i podobieństwa Bożego w czlowieku był jednym $z$ centralnych w antropologii teologicznej autorów wczesnochrześcijańskich, zwłaszcza na Wschodzie ${ }^{2}$. Uzmysławia to statystyka cytowania wierszy $\mathrm{Rdz} 1,26-27$, dokonana na podstawie indeksów zawartych w trzech pierwszych tomach Biblia Patristica ${ }^{3}$. W II wieku główni autorzy chrześcijańscy przywoływali je 115 razy (Klemens - 39 razy, Ireneusz - 43, Tertulian - 32). W III wieku liczba ta zdecydowanie wzrosła. Sam Orygenes odwoływał się do tych werse-

\footnotetext{
${ }^{1}$ Por. Antropologia teologiczna, tłum. z niem. J. Fenrychowa, Kraków 1995, 37.

2 Temat obrazu Bożego w odniesieniu do Chrystusa i każdego człowieka w ujęciu Ojców Kościoła doczekał się wielu szczegółowych opracowań, z których niektóre, obok tekstów źródłowych, zostały częściowo wykorzystane w niniejszym artykule. Swoje monografie w tym zakresie mają tacy wczesnochrześcijańscy autorzy jak: Ireneusz (A. Orbe, Antropologia de San Ireneo, Madrid 1969; E. Peterson, L'imagine di Dio in S. Ireneo, „La Scuola Cattolica” 68:1941, 46-54; J. Fantino, L'homme image de Dieu chez saint Irenée de Lyon, Paris 1986); Tertulian (S. Otto, Der Mensch als Bild Gottes bei Tertullian, „Münchener Theologische Zeitschrift” 10:1959, 276-282); Klemens Aleksandryjski (A. Mayer, Das Bild Gottes nach Klemens von Alexandrien, Roma 1942); Orygenes (H. Crouzel, Théologie de l'image de Dieu chez Origène, Paris 1956); Atanazy (R. Bernard, L'image de Dieu d'après S. Athanase, Paris 1952); Cyryl Aleksandryjski (W.J. Burghardt, The Image of God in Man according to Cyril of Alexandria, Woodstock 1957); Grzegorz z Nyssy (R. Leys, L'image de Dieu chez saint Grégoire de Nysse, Bruxelles - Paris 1951; J.T. Muckle, The Doctrine of St. Gregory of Nysse on Man as the Image of God, „Mediaeval Studies” 7:1945, 5584; Jan Damasceński (J.J. Meany, The Image of God in Man according to the Doctrine of Saint Jean Damascene, Manila 1954). Wykorzystano również syntetyczne opracowanie antropologii patrystycznej L. Dattrino, L'uomo salvato (note di antropologia patristica), Roma, brak r. wyd. (mps).
} 
tów biblijnych w samych zachowanych do dzisiaj nielicznych fragmentach dzieł 135 razy. Inni znani autorzy tego stulecia cytowali powyżse wersety 65 razy (w tym Metody z Olimpu - 7 razy, a Laktancjusz - 23 razy). W IV i V wieku liczba odwołan do tego miejsca biblijnego staje się trudna do policzenia. O rozmiarach, jakie osiągnęły $w$ epoce patrystycznej rozważania na temat miejsca i znaczenia „obrazu Boga”, może świadczyć wypowiedź Epifaniusza z Salaminy, który zwalczając błędne lub niekompletne poglądy dotyczące obrazu Boga w czlowieku, stwierdza z niecierpliwością:

„Nie powinno się absolutnie próbować definiować, gdzie znajduje się obraz [Boga], ale tylko uznawać jego istnienie w człowieku, jeżeli nie chce się niweczyć laski Bożej"4.

W niniejszym artykule zostaną ukazane w zarysie dwa zagadnienia: rozróżnienie obrazu i podobieństwa oraz relacja między nimi nie tylko na płaszczyźnie ontycznej, ale takze historiozbawczej, co przejawiało się w dynamizmie drogi, jaką, według Ojców, człowiek musi przejść od obrazu do podobieństwa do Boga. Dokonam porównania poglądów dwóch autorów najbardziej reprezentatywnych dla interesującego nas zagadnienia: Ireneusza jako wybitnego przedstawiciela tradycji azjatyckiej i Orygenesa jako wiodącego teologa tradycji aleksandryjskiej ${ }^{5}$. Pierwsza ze wspomnianych tradycji jest kategorią bardziej kulturową niż geograficzną, chociaż jej centralnym punktem była Azja Mniejsza. Zapoczątkowana przez Teofila z Antiochii i Melitona z Sardes, znalazla swoich najwybitniejszych przedstawicieli w osobach Ireneusza i Tertuliana. Kładziono w niej akcent na Wcielenie Słowa, na cielesność człowieka i na inne aspekty, które pozwalały mówić o niej jako szkole „materialistycznej” w od. różnieniu od bardziej idealistycznej tradycji aleksandryjskiej. Ta ostatnia miała swoje centrum w Aleksandrii (Klemens, Orygenes, Atanazy, Cyryl Aleksand. ryjski), ale rozciągała się na całe chrześcijaństwo, wpływając ostatecznie także na tradycję azjatycką. Miała ona korzenie platońskie i filońskie.

\section{I. ŹRÓDŁA PATRYSTYCZNEJ ANTROPOLOGII TEOLOGICZNEJ}

Patrystyczna myśl antropologiczna ma, podobnie jak większość tematóv teologicznych, dwojakie źródło: biblijne i filozoficzne. W sformułowaniu dok

${ }^{3}$ Por. Biblia Patristica. Index des citations et allusions bibliques dans la littérature patristique, 1 Des origines à Clément d'Alexandrie et Tertullien, Paris 1975; II: Le troisième siècle (Origèn excepté), Paris 1977; III: Origène, Paris 1980.

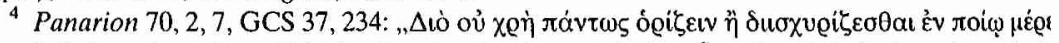

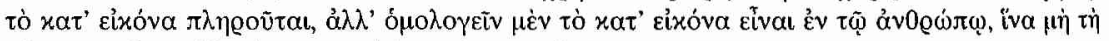

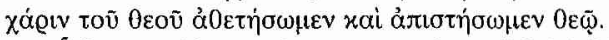

${ }^{5}$ Por. M. Simonetti, Asiatica cultura, DPAC I 414-416; Dattrino, dz. cyt., s. 17-18. 
tryny o obrazie i podobieństwie Boga w człowieku, podstawowej dla patrystycznej antropologii teologicznej, pierwszorzędną rolę odgrywały teksty Pisma św., takie jak: Mdr 7, 24-28; Rz 8, 29; 2Kor 4, 4; Kol 1, 15; Hbr 1, 3; 1J 3, 2. Naczelne miejsce wśród nich zajmował wspomniany fragment Rdz 1, 26-27. Należy pamiętać, że Ojcowie posługiwali się tłumaczeniem Septuaginty (uznawanym wśród pierwszych chrześcijan za natchnione), w którym zwrot Biblii hebrajskiej - „na Nasz obraz, podobnego Nam” został oddany przez sformułowanie ,według Naszego obrazu i Naszego podobieństwa”. To, co w języku hebrajskim należało rozumieć łącznie jako obraz upodabniający, thumaczenie greckie rozdzieliło, stawiając oba terminy obok siebie i łącząc je spójnikiem „นai" ${ }^{\prime \prime}$. Można było potraktować to greckie wyrażenie jako zwykły hendiadys, dla większości Ojców stanowiło ono jednak wystarczający powód do uznania, że oba terminy - „obraz” i „podobieństwo” - różnią się znaczeniowo.

Terminy te miały już swoją historię w starożytnej filozofii platońskiej, było więc czymś normalnym, że pewne ich aspekty znaczeniowe wpłynęły na myśl autorów wczesnochrześcijańskich. Pojęcie obrazu (દixóv) miało u Platona pewną istotną cechę, która znalazła swoje odbicie w antropologii patrystycznej. Obraz oznaczał dla niego rzeczywistość materialną, odbijającą i ukrywająca prawdziwy duchowy świat idei. Dusza jako „coś boskiego"7 nie należy do świata zmysłowego i wymyka się tym samym kategorii obrazu ${ }^{8}$. Obraz, zdaniem Platona, może być tylko materialny, dusza jako boska i duchowa nie może nim być. Reminiscencje takiego sposobu myślenia spotkamy w koncepcji obrazu w antropologii patrystycznej należącej do tradycji azjatyckiej. Na patrystyczną myśl aleksandryjską wpłynęło natomiast nie platońskie rozumienie obrazu, ale jego koncepcja niematerialnej duszy.

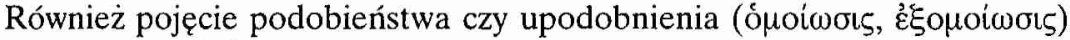
do Boga wywodzi się z myśli platońskiej. Oznaczało ono w niej stawanie się sprawiedliwym i świętym zgodnie $\mathrm{z}$ rozumem i stanowiło duchowe wymaganie obowiązujące mędrca, który miał je realizować przez praktykę cnotliwego życia i ćwiczenie się w kontemplacji ${ }^{9}$. Idea ta rozwinęła się później w kręgach stoickich, gdzie zwrócono uwagę na związek między upodobnieniem do Boga i szczęściem. Jak widać, już w filozofii platońskiej wyraźnie zarysowany był statyczny, wynikający z ontycznej kondycji świata i człowieka, charakter pojęcia „obraz" oraz dynamiczny, związany z działaniem człowieka, charakter pojęcia „podobieństwo”. Obraz się miało lub się nim było, natomiast do podobieństwa się dążyło i trzeba było je zdobyć. To napięcie między obrazem Boga

${ }^{6}$ Por. S. Otto, Gottes Ebenbild in Geschichtlichkeit. Überlegungen zur dogmatischen Anthropologie, München 1964, 59; Langemeyer, dz. cyt., s. 83.

${ }^{7}$ Plato, Phaedo $95 \mathrm{c}$.

${ }^{8}$ Por, tenże, Leges XII 959b.

9 Tenże, Theaetetus $176 \mathrm{AB}$; Republica VI 13. 
a podobieństwem do Niego w człowieku, nie występujące w Piśmie św., stało się decydującą inspiracją dla teologów wczesnochrześcijańskich.

\section{PODSTAWOWE ZAEOŻENIA WSPÓLNE DLA IRENEUSZA I ORYGENESA}

Jak już wspomniano w uwagach wstępnych, dwie główne tradycje wczesnopatrystyczne - azjatycka i aleksandryjska - różnily się w wielu istotnych sprawach, także dotyczących antropologii teologicznej. Zanim jednak zostanie ukazana specyfika każdej $z$ nich $w$ kwestii obrazu i podobieństwa, należy wspomnieć o kilku zasadniczych przekonaniach wspólnych dla obu tradycji, a tym samym dla dwóch interesujących nas autorów.

Po pierwsze, przedstawiciele obu tradycji, z nielicznymi wyjątkami (Atanazy, Grzegorz z Nyssy, Cyryl Aleksandryjski) byli przekonani o konieczności rozróżnienia znaczeniowego obu terminów, chociaż rozumieli je nieco inaczej. Pierwszy znany nam $z$ zachowanych dziel przedstawiciel tradycji aleksandryjskiej - Klemens - mówi o tym rozróżnieniu już jako znanym w środowisku chrześcijańskim:

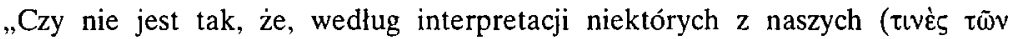
$\hat{\eta} \mu \varepsilon \tau \varepsilon \dot{\varepsilon}(\omega v)$, czlowiek otrzymał od razu przy narodzeniu obraz, a później, o ile stanie się doskonały, przyjmie do siebie podobieństwo ?"10.

Nie wiadomo, do kogo odwołuje się tu Klemens, ale nie jest wykluczona aluzja do Ireneusza z Lyonu, głównego przedstawiciela tradycji azjatyckiej, który systematycznie używa powyższego rozróżnienia ${ }^{11}$. W każdym razie jest niekwestionowanym faktem, nawet jeżeli Klemens nie zdawal sobie $\mathrm{z}$ tego sprawy, że zarówno dla teologów z Azji Mniejszej, jak i z Egiptu w 2. poł. II wieku terminy „obraz” i „podobieństwo” w tekście Rdz 1, 26-27 należało znaczeniowo odróżniać.

Po drugie, większość pisarzy epoki patrystycznej, niezależnie od tradycji,

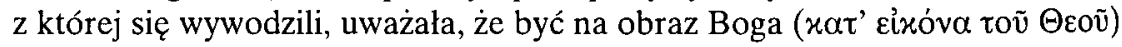
i być obrazem Boga to nie to samo. Już Filon thumaczyl, że tylko Logos jest prawdziwym obrazem i że czlowiek może pretendować jedynie do bycia „obrazem obrazu"12. Takie ujęcie będzie $z$ naciskiem lansował wśród Aleksandryjczyków Orygenes: tylko Chrystus jest obrazem Boga we właściwym tego słowa znaczeniu, człowiek natomiast został stworzony na obraz, czyli na wzór obrazu,

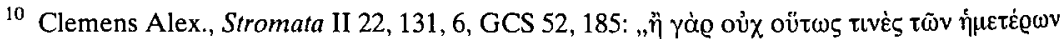

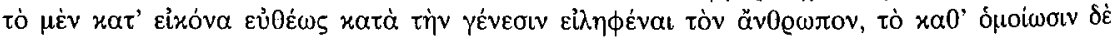

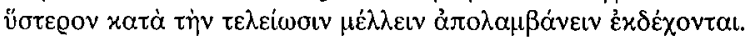

11 Por. Irenaeus, Adversus haereses V 16, 2.

12 Por. De opificio mundi 24-25; Legum allegoriae III 96; Quis rerum divinarum heres sit 230-231. 
a więc na wzór Chrystusa i jest Jego obrazem ${ }^{13}$. Również reprezentujący tradycję azjatycką Ireneusz, komentując tekst $\mathrm{Rdz} 1,26$ stwierdza, choć w zupełnie innym kontekście niż Aleksandryjczycy, że modelem, na podstawie którego Adam został stworzony przez Boga, jest wcielony Syn Boży - Logos i On właściwie zasługuje na miano obrazu Boga ${ }^{14}$. Ireneusz uważał wprawdzie, że obrazem Boga, służącym za wzór dla stworzenia człowieka był Logos wcielony, a nie preegzystujący, jak sądził Orygenes, ale idea uznania człowieka tylko jako obrazu właściwego obrazu, jakim jest Chrystus, niezależnie od tego, czy duchowy czy wcielony, jest obu autorom wspólna.

Po trzecie, wspólne było $\mathrm{w}$ okresie wczesnopatrystycznym przekonanie o dynamice zachodzącej między obrazem a podobieństwem. I jedno, i drugie można utracić (obraz tylko częściowo, podobieństwo nawet całkowicie). O utrzymanie, a także rozwój jednego i drugiego trzeba zabiegać (wyraża to

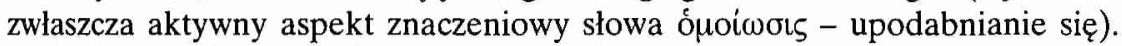
Podobieństwo jest jednak jakby doskonalszą, ostateczną postacią obrazu i do niego ma zmierzać życie prawdziwego chrześcijanina, niezależnie od tego, jak owo podobieństwo w detalach się rozumie. Ono jest, zarówno dla Ireneusza, jak i Orygenesa, celem drogi doskonalenia, znakiem czasów ostatecznych, zapowiedzią prawdziwego życia w łączności z Bogiem.

\section{STANOWISKO IRENEUSZA}

Według Ojców Kościoła Chrystus - Logos jest obrazem, służącym jako

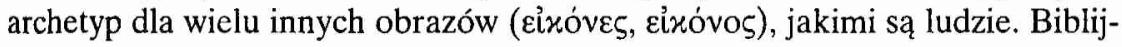
nym punktem wyjścia dla takiego rozumienia byl tekst Kol 1, 15, w którym Pawel interpretował chrystologicznie stwierdzenie z Rdz 1, 26-27, uważając, że tylko dostosowując się do Chrystusa - Obrazu Ojca, czlowiek może stać się autentycznym obrazem Boga. Ireneusz i Orygenes byli co do tego zgodni, radykalna różnica zachodziła natomiast $w$ identyfikacji obrazu Boga $z$ konkretnymi fazami istnienia Boskiego Logosu. Pierwszy odnosił Słowo-Obraz do Slowa Wcielonego (imago qua Deus-homo), drugi zaś do Słowa preegzystującego (imago qua Deus) $)^{15}$.

Podstawowy tekst Ireneusza dotyczący interesującego nas zagadnienia brzmi:

„Niegdyś mówiono, że człowiek został uczyniony na obraz Boga, nie było to jednak widoczne, ponieważ Słowo, na obraz którego został uksztaltowany, było

${ }^{13}$ Por. Contra Celsum VI 63; VII 66. Zob. także Athanasius, Contra gentes 2-3; De incarnatione Verbi 12-13; H. Crouzel, Orygenes, tłum. z franc. J. Margański, Bydgoszcz 1996, 257.

${ }^{14}$ Por. Adversus haereses V 16, 1-2; IV 33, 4.

15 Por. Dattrino, dz. cyt., s. 24. 
jeszcze niewidzialne [...]. Gdy jednak Slowo Boże stało się ciałem, [...] ukazało prawdę o obrazie, samo stając się tym, czym był jego obraz [...]"16.

W kontekście polemiki $\mathrm{z}$ antymaterialistycznie nastawionymi gnostykami, którzy uważali, że czlowiek ziemski ma za wzór należącego do pleromy Bogaczłowieka, Ireneusz przyjmuje koncepcję głoszącą, że Bóg, na obraz którego został stworzony człowiek, powinien być Bogiem-człowiekiem, ale nie bytem niebiańskim i mitycznym, lecz realnym, historycznym Słowem Wcielonym Jezusem Chrystusem. Obrazem Boga, służącym jako wzór dla stworzenia czlowieka był więc, dla Ireneusza, nie preegzystujący Logos, ale Syn Boży Wcielony, co człowiek mógł w pełni odkryć dopiero po przyjściu Chrystusa na ziemię. Zgodnie z taką koncepcją obraz Boga w człowieku w sposób konieczny implikuje Wcielenie i ukierunkowuje stworzenie Adama na jego calkowite spełnienie w Chrystusie - który zbawia i rekapituluje w sobie ludzkość ${ }^{17}$.

Według Ireneusza podmiotem obrazu Bożego jest więc Chrystus historyczny. W porządku chronologicznym czlowiek niedoskonały jest wcześniejszy od doskonałego, ale w porządku myślowym (w umyśle Boga) pierwsze miejsce zajmuje Człowiek idealny, tzn. ciało $(\pi \lambda \alpha \dot{\alpha} \mu \alpha)$, w którym Boski Logos wyciska swój charakter. Patrząc na tego Człowieka idealnego, umieszczonego w centrum historii, Bóg stworzył pierwszego człowieka. W Adamie Bóg naśladuje swoje Słowo Wcielone. Dla Ireneusza „ekonomia wcielenia Syna Bożego" rozpoczyna się od momentu stworzenia człowieka, jeszcze przed grzechem ${ }^{18}$.

Istotnym problemem $w$ ramach patrystycznej antropologii teologicznej była próba odpowiedzi na pytanie, gdzie dokładnic w człowieku znajduje się obraz Boży. U podstaw nauki Ireneusza na ten temat leżala polemika antygnostycka, przeciwstawiająca się platońsko-gnostyckiemu poglądowi, zgodnie z którym to, co materialne, nie jest godne zbawienia ${ }^{19}$. Ów motyw antygnostycki jest ściśle związany z przekonaniem lokującym obraz Boga w ciele czlo-

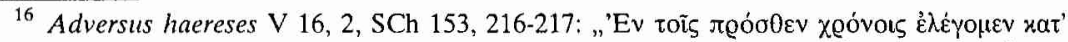

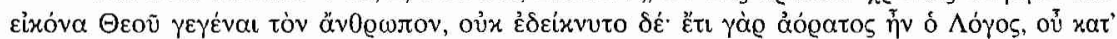

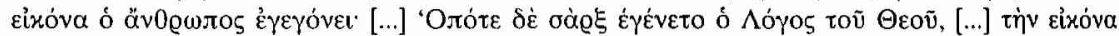

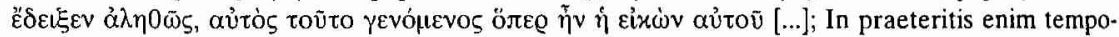
ribus, dicebatur quidem secundum imaginem Dei factum esse hominem, non autem ostendebatur: adhuc enim invisibile erat Verbum, cuius secundum imaginem homo factus fuerat; [...] Quando autem caro Verbum Dei factum est, [...] imaginem enim ostendit veram, ipse hoc fiens quod erat imago eius [...]".

${ }_{17}$ Podobne sformułowania jak u Ireneusza znajdujemy u innego przedstawiciela tradycji azjatyckiej -Tertuliana: „W tym wszystkim, co wyraża się poprzez proch ziemi ( $\operatorname{Rdz} 2,7)$, myśli się o Chrystusie; o tym, który miał stać się czlowiekiem (homo futurus), czyli prochem; o Słowie, które miało stać się ciałem, powstałym z tego, co było najpierw ziemią" (De resurrectione carnis 6 , 3-4, CCL 2, 928; por. Adversus Praxean 12, 4; Adversus Marcionem V 8, 1).

${ }^{18}$ Por. Adversus haereses V 20, 1, SCh 153, 254-255.

${ }^{19}$ Por. krytykę poglądów Bazylidesa i Marcjona w Adversus haereses I 19, 3; I 25, 2. 
wieka. Biskup Lyonu broni przede wszystkim jedności człowieka. Uznaje wprawdzie ontyczny trójpodział bytu ludzkiego na ciało, duszę i Ducha, idąc za 1 Tes 5,23 , ale podkreśla przeciw gnostykom, że nie można zredukować go do jednego $z$ tych konstytutywnych elementów, szczególnie do duszy lub ducha. Według Ireneusza cały człowiek jest podmiotem zbawienia przez Boga, co implikuje również zbawienie ciała po zmartwychwstaniu. Co więcej, przeciwko pesymizmowi ontologicznemu postponującemu ciało jako źródło zła, Ireneusz

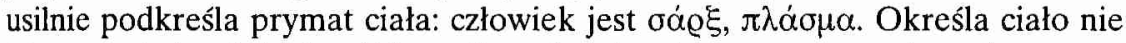
jako przedmiot dekadencji i upadku, ale jako skromny początek zaplanowany w procesie doskonalenia ( $\varepsilon \varepsilon \lambda \varepsilon i \omega \sigma ı \zeta)$. Potępianie ciała świadczy, według biskupa Lyonu, o niezrozumieniu istoty misterium chrześcijańskiego: stworzenia, wcielenia i odkupienia ${ }^{20}$.

Należy pamiętać, że skoro, zdaniem Ireneusza, człowiek został stworzony na obraz Słowa wcielonego, ciało ludzkie nie jest obrazem Bóstwa, ale obrazem ciała Chrystusa. Ireneusz, podobnie jak inni przedstawiciele tradycji azjatyckiej, nie uznaje schematu ,podwójnego stworzenia” (najpierw człowieka duchowego, a potem cielesnego), charakterystycznego dla Aleksandryjczyków, ale interpretując oba opisy stworzenia z Księgi Rodzaju w sposób komplementarny, kładzie akcent właśnie na ciało $(\pi \lambda \alpha \dot{\sigma} \sigma \alpha)$. Człowiek składa się z trzech elementów, ale istotną rolę odgrywa ciało, zdolne do przyjęcia Ducha i do uwielbienia. Pewne usunięcie w cień roli duszy ludzkiej, która wydaje się traktowana przez niego instrumentalnie, jakby na usługach ciała, należy tłumaczyć wymaganiami polemiki antygnostyckiej, które zmuszały do skoncentrowania uwagi przede wszystkim na zbawieniu ciała.

Jak już wspomniałem, rozróżnienie znaczeniowe między terminami „obraz" i „podobieństwo", wywodzące się z interpretacji tekstu biblijnego Rdz 1 , 26-27 w wersji Septuaginty, stanowiło wspólny element różnych tradycji okresu patrystycznego. Mimo tego, każdy niemal autor wczesnochrześcijański proponował swoje rozwiązanie szczegółowe co do znaczenia obu terminów. Rozróżnienie semantyczne między „obrazem” a „podobieństwem” jest obecne „implicite" w całym dziele Adversus haereses Ireneusza, ale w sposób najbardziej wyraźny występuje w księdze $\mathrm{V}$, dotyczącej głównie zagadnienia zmartwychwstania ciała ${ }^{21}$. „Obraz” (Eixóv, imago) zachowuje u biskupa Lyonu zawsze cechy zewnętrzności i widzialności. Formuła „na obraz Boga” odnosi się u niego najczęściej do „ciała” jako elementu widzialnego, czasem też do całego człowieka ${ }^{22}$, w tym kontekście używa jednak zazwyczaj zwrotu: „na obraz i pod-

\footnotetext{
${ }^{20}$ Por. Adversus haereses V 6, 1-7, 2, SCh 153, 72-92.

${ }^{21}$ Por. zwl. trzy teksty: V 6, 1, SCh 153, 72-80; V 11, 2, SCh 153, 136-140; V 16, 2, SCh 153, 216.

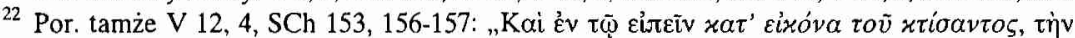

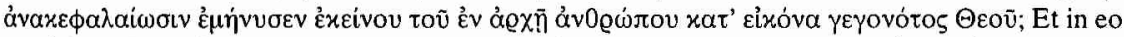
quod dicit: Secundum imaginem conditoris, recapitulationem manifestavit eius hominis qui in initio secundum imaginem factus est Dei".
} 


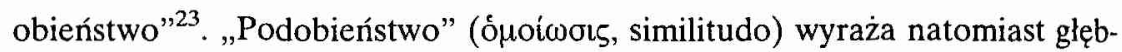
sze upodobnienie, element dynamiczny koniecznie potrzebny do pełnego przylgnięcia do Boga. Rozróżnienie między dwoma terminami ujawnia się w calej pełni w następującym tekście Ireneusza:

„Doskonały czlowiek jest zmieszaniem i zjednoczeniem duszy przyjmującej Ducha Ojca, i dołączonego do niej ciala, które jest ukształtowane według obrazu Boga [... Człowiek] ma obraz [Boga] w uksztattowaniu [cielesnym], podobieństwo zaś [...] otrzymuje przez Ducha $[\ldots]^{, 24}$.

W teologii Ireneusza istotną rolę odgrywa odziedziczony z wcześniejszej tradycji (Klemens Rzymski, Teofil Antiocheński) obraz dwóch rąk Boga, jakimi są Slowo i Mądrośćc ${ }^{25}$, czyli Syn i Duch ${ }^{26}$. Podobnie jak obraz dwóch rąk oznacza współpracę Syna i Ducha z Ojcem w dziele stworzenia, tak też wyrażenie „na obraz i podobieństwo Boże” wskazuje na podwójną pieczęć.wyciśniętą przez Syna i Ducha na człowieku: obraz w ciele, w odniesieniu do Słowa, które miało przyjąć ciało; podobieństwo dzięki uczestnictwu w Duchu Świętym ${ }^{27}$. Jednak Ireneusz, jak zauważa A. Orbe ${ }^{28}$, wydaje się lokalizować podobieństwo do Boga nie tylko w uczestnictwie w Duchu Świętym, ale w samym fakcie bycia człowiekiem jako stworzeniem rozumnym i wolnym ${ }^{29}$.

Problem znaczenia obu terminów i ich odniesienia do konkretnych miejsc w człowieku jest u Ireneusza w ogóle delikatny i złożony. Na pierwszy rzut oka może się wydawać, że Ireneusz umieszcza podobieństwo do Boga w duszy

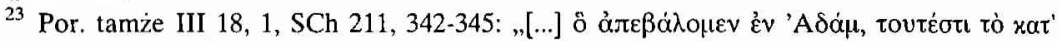

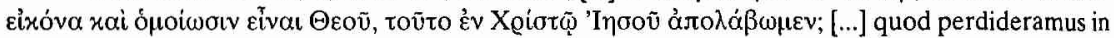
Adam, id est secundum imaginem et similitudinem esse Dei, hoc in Christo iesu reciperemus";

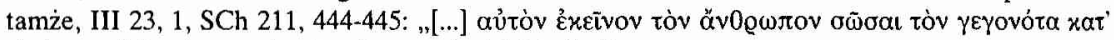

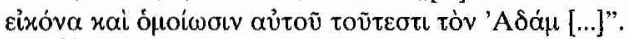

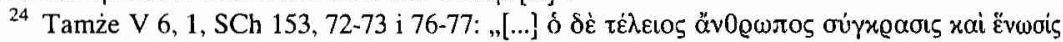

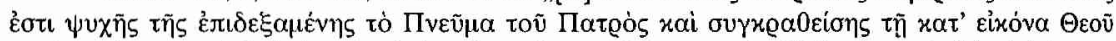

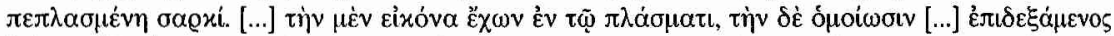

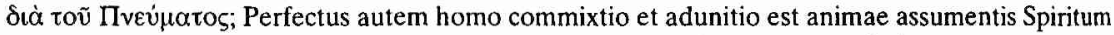
Patris, et admixtae ei carnis, quae est plasmata secundum imaginem Dei [...] Imaginem quidem habens in plasmate, similitudinem vero [...] assumens per Spiritum".

${ }^{25}$ Por. tamże II 30, 9, SCh 294, 318-320: ,[...] solus Omnipotens et solus Pater, condens et faciens omnia [...] Verbo virtutis suae, et omnia aptavit etdisposuit Sapientia sua [...]".

${ }^{26}$ Por. tamże IV, praef. 4, SCh 100/2, 390: „Homo est enim temperatio animae et carnis, qui secundum similitudinem Dei formatus est et per manus eius plasmatus est, hoc est per Filium et Spiritum [...]".

27 Tamże V 6, 1, SCh 153, 762: „[...]imaginem quidem habens in plasmate, similitudinem vero [...] accipiens per Spiritum [...]".

${ }^{28}$ Por. Orbe, dz. cyt., s. 133-142.

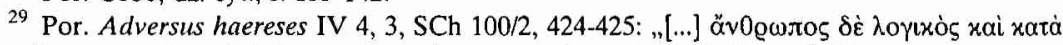

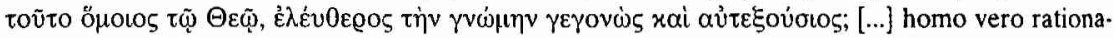
bilis, et secundum hoc similis Deo, liber in arbitrio factus et suae potestatis [...]". 
ludzkiej, co korespondowałoby $\mathrm{z}$ umieszczaniem przez niego obrazu Boga w ludzkim ciele. A. Orbe ${ }^{30}$ uważa jednak, że biskup Lyonu odnosi oba określenia do ciała, chociaż czyni to $\mathrm{z}$ różnych względów. Orbe powołuje się na tekst z mniej znanego dziełka Ireneusza Wykład nauki apostolskiej:

„Bóg ukształtował czlowieka wlasnymi rękami, biorąc z ziemi to, co najczystsze i najdelikatniejsze i mieszając według odpowiedniej miary swoją moc z ziemią. [...] $\mathrm{Na}$ obraz Boga został postawiony na ziemi uksztaltowany człowiek i aby stał się istotą żyjącą tchnął w jego oblicze dech życia, aby w ten sposób tak według tchnienia $(\dot{\varepsilon} \mu \phi \dot{\sigma} \sigma \eta \mu \alpha)$ jak i według ukształtowania $(\pi \lambda \dot{\alpha} \sigma \mu \alpha)$ człowiek stał się podobny Bogu"31.

Orbe dochodzi do wniosku, że, według Ireneusza, na początku stworzenia zostały przez Boga pomieszane dwa elementy: proch ziemi i moc Boża, pochodząca od dwóch rąk Boga - Syna i Ducha Świętego. Za formę zewnętrzną byl w człowieku odpowiedzialny Syn Boży - prawdziwy Obraz Ojca, natomiast za formę wewnętrzną Duch Święty - prawdziwe Podobieństwo do Ojca. Ciało ludzkie jest więc w swoim aspekcie widzialnym obrazem Obrazu Ojca, czyli jest stworzone „na obraz Boga”, a w aspekcie wewnętrznym jest „,na podobieństwo Boże". Ciało, chociaż ukształtowane $(\pi \lambda \dot{\alpha} \sigma \mu \alpha)$, nie było zdolne samo, jako element pasywny, odpowiedzieć na wymagania Ducha Świętego. Potrzebay był element wiążący. W tym celu Bóg umieścił w ciele duszę, czyli tchnienie zycia, wprowadzające je w ruch. Godność człowieka nie pochodzi jednak tak bardzo $z$ duszy, jak z ciała, uczynionego na obraz i podobieństwo Boże. Dusza $\left(\psi v \chi \eta^{\prime}\right)$ jest funkcją ciała, instrumentem umożliwiającym mu zjednoczenie z Bogiem, istotnym środkiem służącym ubóstwieniu ciała. Gdy wypełni ona to zadanie, pozostanie wprawdzie substancjalnie częścią bytu ludzkiego, prze-

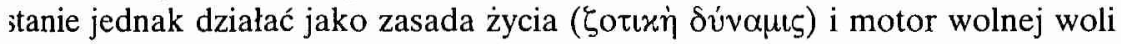

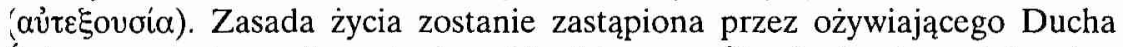
Świętego, a wolna wola zostanie wchłonięta przez $\dot{\varepsilon} \lambda \varepsilon v \theta \varepsilon \rho i \alpha$, dar pełni escha:ologicznej. Cała ta koncepcja, jak podkreśla Orbe, ma podłoże antygnostyckie. Nie ma, według Ireneusza, trzech typów człowieka, ale jest jedna natura

${ }^{30}$ Por. Orbe, dz. cyt., s. 57-77; Dattrino, dz. cyt., s. 46-48.

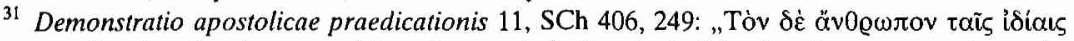

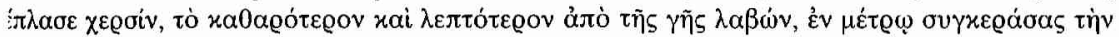

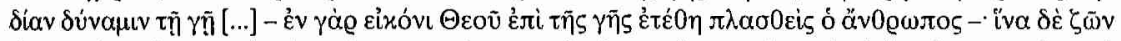

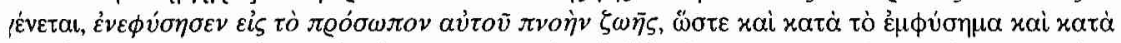

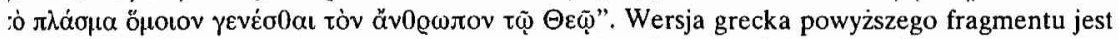
ekonstrukcją dokonaną przez A. Rousseau na podstawie lacińskiej kalki tekstu ormiańskiego: ,Hominem autem propriis plasmavit manibus, (id quod) purissimum (est) et tenuissimum-etlelicatissimum de terra sumens, ad mensuram in-unum-miscens suam virtutem cum terra. [...] Id imaginem enim Dei super terram positus est plasmatus homo - ut autem vivens fieret, insufflavit $n$ faciem eius spiraculum vitae, ita ut et secundum insufflationem et secundum plasma similis fieret Iomo Deo" (SCh 406, 98), tłum. W. Myszor, ŹMT 7, 33. 
ludzka, złożona z trzech integralnych części (ciała, duszy i Ducha, utożsamianego z Duchem Świętym), tworzących razem człowieka doskonałego. Jest jednak między nimi pewna hierarchia. Substancją w ścisłym tego słowa znaczeniu jest plazma, czyli ukształtowane ciało, natomiast dusza i Duch nie są w czlowieku substancjami autonomicznymi, ale związanymi z plazmą w istnieniu i działaniu. Wszystko jest uporządkowane w ciele, stanowiącym centrum ekonomii zbawienia. Tak więc, chociaż podobieństwo uzyskuje się przez Ducha Świętego i chociaż odnosi się ono do rzeczywistości niestworzonej i boskiej, obejmuje właściwie dwa elementy: Ducha Świętego - element upodabniający i cialo - element upodabniany. Dusza, narzędzie upodobnienia, jest równiez przedmiotem upodobnienia przez Ducha Świętego, ale upodobnienie we właściwym znaczeniu realizuje się w ciele.

Dla większości Ojców greckich rozróżnienie między obrazem i podobieństwem odpowiada rozróżnieniu między porządkiem ontycznym a moralnym. Obraz się posiada, podobieństwo się z czasem zdobywa bądź doskonali. Sam obraz również nie jest rzeczywistością wyłącznie statyczną, gdyż na skutek grzechu pierworodnego uległ on zatarciu i należało przywrócić mu pierwotny blask. W oba pojęcia wpisane jest również historyczne napięcie między przeszłością, teraźniejszością a eschatologią, w której nastąpi ich ostateczne spełnienie. Tak więc dynamizm patrystycznej antropologii teologicznej wpisuje się wyraźnie w historię zbawienia. Ireneusz przypisuje pewien rodzaj dynamizmu każdemu z obu pojęć i sytuuje je w historii. Obraz Boży ujawnia się coraz bardziej i zmierza do przyjęcia podobieństwa, które również ulega ciągłemu doskonaleniu. Biskup Lyonu nazywa ten proces uświadamianiem przez Boga człowiekowi jego godności obrazu Bożego i stopniowym przygotowywaniem człowieka do „noszenia Ducha" ${ }^{32}$. W kluczowym tekście z Adversus haereses czytamy:

„Niegdyś mówiono, że czlowiek został uczyniony na obraz Boga, nie bylo to jednak widoczne, ponieważ Słowo, na obraz którego został ukształtowany, było jeszcze niewidzialne. Również podobieństwo uległo szybkiej utracie. Gdy jednak Słowo Boże stało się ciałem, odnowiło obraz i podobieństwo, ponieważ, stając się człowiekiem, ukazalo prawdę o obrazie, samo stając się tym, czym był jego obraz. Wycisnęło ono również w człowieku głęboko podobieństwo, czyniąc go na nowo podobnym przez widzialne Słowo do niewidzialnego Ojca" ${ }^{\text {"33 }}$.

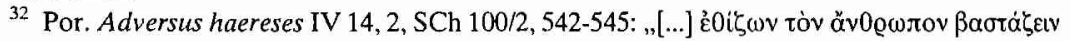

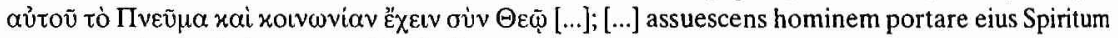
et communionem habere cum Deo [...]".

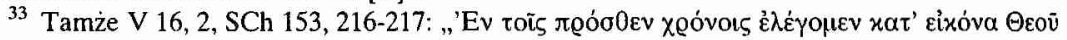

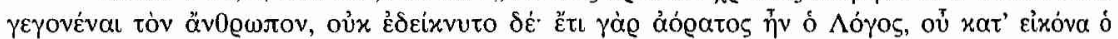

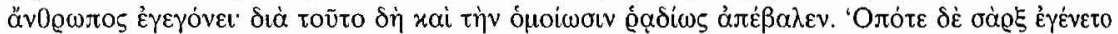

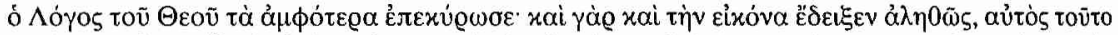

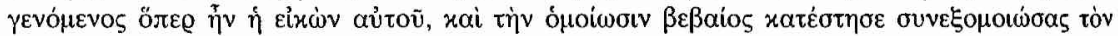

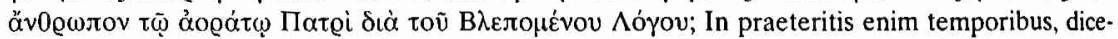


Jak wynika z powyższego tekstu, ciało ludzkie Słowa Bożego - model naszego ciała - w czasach poprzedzających Wcielenie Logosu nie ukazało się w sposób widzialny i dlatego dusza ludzka odwróciła się od Ducha Świętego, tracąc czy, jak uważa Orbe, raczej osłabiając w sobie podobieństwo, gdyż to właśnie Duch jest mocą upodabniającą do Boga. Wraz z wcieleniem obraz i podobieństwo do Boga zostały odnowione w ludziach i muszą ulegać dalszemu doskonaleniu.

Pierwotne podobieństwo, zdaniem Ireneusza, podobnie jak jego poprzednika Teofila ${ }^{34}$, nie stanowiło, jak można by przypuszczać, stanu ostatecznej doskonałości, niezniszczalności i nieśmiertelności, a jedynie podstawowe wprowadzenie $w$ ten stan. Podobieństwo związane $z$ mocą Ducha Świętego zostało wsiane w człowieka, czy, bardziej precyzyjnie, w jego ciało, i poddane prawu ciągłego wzrostu: od podobieństwa wstępnego do pełni Ducha i nieśmiertelności, koronującej proces postępu ${ }^{35}$. Można powiedzieć za P. Evieux ${ }^{36}$, że człowiek uczestniczy już w Bogu i Go przyjmuje (accipere, percipere), ale nie jest jeszcze w stanie Go pochwycić i zawrzeć w sobie (capere, continere). Stopniowe formowanie czlowieka zajmuje cały czas historii: od inicjalnego $\pi \lambda \dot{\alpha} \sigma \iota \zeta$ do finalnego $\dot{\alpha} v \alpha \pi \lambda \dot{\alpha} \sigma \iota \zeta$. Jak pisze Ireneusz, „dziełem Boga jest uksztaltowanie człowieka" ${ }^{37}$. Powyższe zdanie podkreśla, że pierwszorzędną rolę w tym procesie ciągłego kształtowania człowieka odgrywa Bóg i Jego łaska, On jest główną siłą sprawczą dojrzewania czlowieka. To Bóg w swojej zbawczej pedagogii, uwzględniającej wolność czlowieka i prawo stopniowego, a nie gwałtownego rozwoju, wpisane w jego byt ${ }^{38}$, przyzwyczaja go powoli do niezniszczalności. Tylko Duch Święty - podobieństwo do Boga „sensu stricto et pleno" - może doprowadzić człowieka do pełnego i wiecznego oglądania Bo$\mathrm{ga}^{39}$. Ireneusz dowodzi, że na razie, gdy trwa czas historii, nawet już po Wcieleniu Chrystusa, posiadamy wciąż tylko cząstkę Ducha Świętego (por. Ef 1, 13; Rz 8, 15). Gdy jednak przyjdzie pełnia Ducha Świętego w momencie zmar-

batur quidem secundum imaginem Dei factum essem hominem, non autem ostendebatur: adhuc enim invisibile erat Verbum, cuius secundum imaginem homo factus fuerat; propter hoc autem et similitudinem facile amisit. Quando autem caro Verbum Dei factum est, utraque confirmavit: et imaginem enim ostendit veram, ipse hoc fiens quod erat imago eius, et similitudinem firmans restituit, consimilem faciens hominem invisibili Patri per visibile Verbum".

${ }^{34}$ Por. Ad Autolycum II 24.

${ }^{35}$ Por. Orbe, dz. cyt., s. 228-236.

${ }^{36}$ Por. Théologie de l'accoutumance chez Saint Irenée, ,Recherches de Science Religieuse” 55 (1967) 5-54.

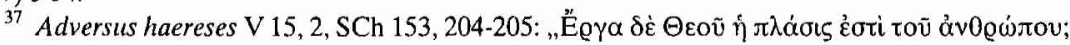
Opera autem Dei plasmatio est hominis"; por. Dattrino, dz. cyt., s. 56-57.

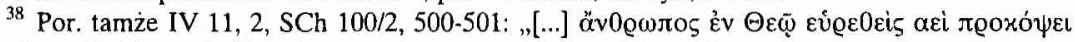

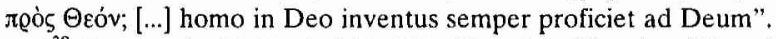

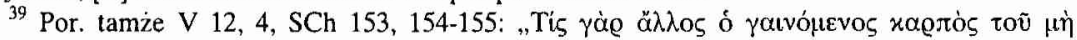

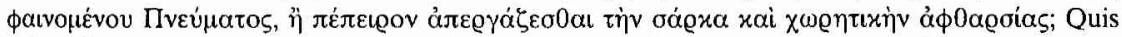
enim alius apparens fructus eius est qui non apparet Spiritus, quam maturam efficere carnem et capacem incorruptelae?"; por. tamże III $24,1$. 
twychwstania umarlych, uczyni On nas w pełni podobnymi do Boga, odnawiając w człowieku całkowicie obraz i podobieństwo. Tak więc, według Ireneusza obraz, a zwłaszcza podobieństwo Boże w człowieku zmierza ku eschatologicznemu spełnieniu u kresu historii zbawienia. Wówczas Duch Święty przekształci ostatecznie ludzkie ziemskie ciała w nieśmiertelne.

\section{STANOWISKO ORYGENESA}

W środowisku aleksandryjskim dyskusję nad kwestią Chrystusa jako obrazu Bożego zapoczątkowal w sposób niesystematyczny już Klemens, ale właściwą jego wykładnię dał dopiero Orygenes. Oparł on polemikę z tradycją azjatycką na zagadnieniu bezcielesności Boga, nazywając ludźmi cielesnymi tych, którzy przez fakt odnoszenia obrazu Boga do ciała człowieka, wydają się twierdzić, że Bóg jest cielesny ${ }^{40}$. W rzeczywistości jednak przedstawiciele tradycji azjatyckiej odnosili bycie na obraz nie do Boga cielesnego i antropomorficznego, ale do Boga wcielonego, czyli do Chrystusa ${ }^{41}$.

Powyższy problem był jednak dla Orygenesa tylko pretekstem, jego antropologia teologiczna zakorzeniona jest bowiem w ogólnej wizji Boga, świata i człowieka, inspirowanej pośrednio platonizmem czy raczej bezpośrednio średnim platonizmem Filona Aleksandryjskiego. Orygenes przejmuje spirytualizm i idealizm platoński, wprowadza jednak w kwestii obrazu kategorię nieznaną ani Platonowi, ani wcześniejszej tradycji chrześcijańskiej: pojęcie obrazu niewidzialnego. Odnosząc je do tekstu Kol 1, 15 pisze, że Chrystus, będąc obrazem Boga niewidzialnego, jest również obrazem niewidzialnym ${ }^{42}$. Dla Orygenesa obrazem Boga nie jest więc Slowo wcielone, jak to miało miejsce w przypadku Ireneusza, ale preegzystujący i niewidzialny Logos (imago qua Deus) ${ }^{43}$. Ujmując rzecz ściślej, według Orygenesa, pierwszym stworzeniem na obraz Boga, czyli pierwszym obrazem obrazu, była dusza samego Jezusa, wzór dla ludzi. Odwiecznie zjednoczona z Logosem, wstępuje ona do Boga po swoim

${ }^{40}$ Por. Homiliae in Genesim I 13, 15-23, SCh 7bis, 58: „Si qui vero hunc corporeum putet esse, qui ad imaginem et similitudinem Dei factus est, Deum ipsum corporeum et humanae formae videtur inducere; quod sentire de Deo manifestissime impium est. Deniqui carnales isti homines qui intellectum divinitatis ignorant, sicubi in Scripturis de Deo legunt quia caelum mihi sedes terra autem scabellum pedum meorum (Iz 66, 1), suspicantur Deum tam ingentis esse corporis, ut putent eum sedentem in caelo pedes usque ad terram protendere".

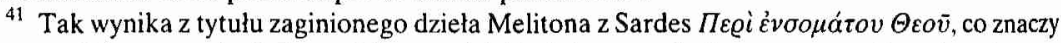
$O$ Bogu wcielonym, a nie $O$ Bogu cielesnym, jak błędnie sugeruje Orygenes, por. Dattrino, dz. cyt., s. 28.

${ }^{42}$ Por. De principiis I 2, 6, SCh 252, 120 i 124: „[...] invisibilis Dei imago invisibilis est [...]. Imago ergo est invisibilis Dei Patris Salvator noster".

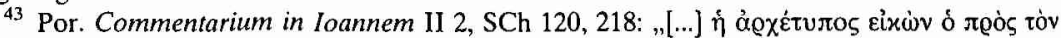

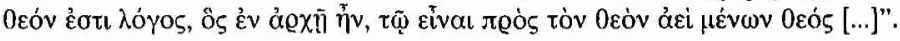


zwycięstwie nad śmiercią, pociągając za sobą dusze wiernych. Dusza Chrystusa, obraz Obrazu, prowadzi duszę ludzką, ukształtowaną „na obraz Boży”, do pełnej realizacji w niej obrazu Logosu ${ }^{44}$. Tradycja wywodząca się od Orygenesa zdominuje całą antropologię patrystyczną na Wschodzie i Zachodzie, przypisując Ojcom opinię platoników czy raczej filoników ${ }^{45}$.

Kwestia obrazu Bożego w człowieku była ujmowana przez Orygenesa również inaczej niż u Ireneusza. W tradycji aleksandryjskiej człowiek uksztaltowany na obraz Boga to nie człowiek integralny, a tym bardziej nie jego ciało, jak to miało miejsce w tradycji azjatyckiej, ale dusza, czy raczej „voũ $\varsigma^{\prime \prime}$ (mens),

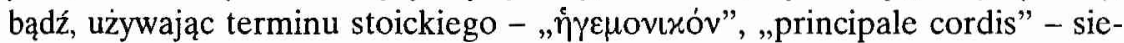
dziba poznania, wolności i każdej cnoty. Tylko pośrednio delikatność obrazu odbija się w ciele, które, nie mogąc uczestniczyć w niewidzialnej i duchowej naturze obrazu, sytuuje się na niższym poziomie. Człowiek jest więc obrazem nie w biblijnym sensie Rdz 1, 26-27 ani w rozumieniu Pawłowym, łączącym ściśle Kol 1, 15 z Rdz 1, 26-27 i z 1Kor 15, 45-49, czyli uznającym za obraz Boży całego człowieka, ale na wzór greckiej koncepcji filozoficznej.

Już pierwszy Aleksandryjczyk Klemens twierdzil, że wyrażenie „na obraz i podobieństwo Boże" nie odnosi się do ciała, ponieważ jest czymś niedopuszczalnym, by śmiertelne było podobne do nieśmiertelnego, ale do intelektu, do rozumu $^{46}$. Głównym teoretykiem aleksandryjskiej koncepcji obrazu jest jednak Orygenes. Wykorzystuje on filoński schemat „podwójnego stworzenia”, według którego na obraz został uczyniony człowiek stworzony, a nie ulepiony $\mathrm{z}$ ziemi. Na potwierdzenie tego rozróżnienia wprowadza także Pawłowy podział na czlowieka wewnętrznego i zewnętrznego. Orygenes nie uważa wprawdzie, że ciało jest źródłem zła, ale podkreśla godność człowieka uczynionego na obraz Boży, która zawiera się w niematerialnej duszy, a bardziej precyzyjnie w umyśle „nous”, czyli jej wyższej części, gdyż tylko intelekt może poznać Boga i upodobnić się do Niego. Oto zawierający powyższe tezy tekst z Homilii o Księdze Rodzaju:

„Nie identyfikujemy tego człowieka, o którym Pismo mówi, że zostal uczyniony na
«obraz Boży» z czlowiekiem cielesnym. To nie postać cielesna ma w sobie obraz
Boga. Zresztą nie mówi się, że człowiek cielesny zostal «uczyniony», ale że został
«ulepiony» (por. Rdz 2,7) [...]. To, co zostało uczynione na obraz Boga, to nasz
czlowiek wewnętrzny, niewidzialny, bezcielesny, niezniszczalny i nieśmiertelny.
[...] Jeżeli ktoś utrzymuje, że na obraz i podobieństwo Boże został uksztaltowany

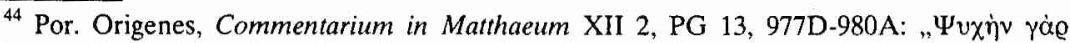

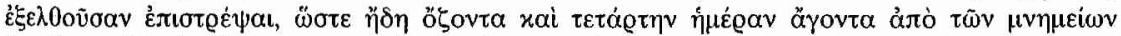

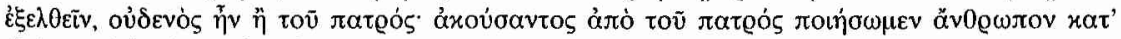

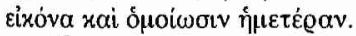

${ }^{45}$ Por. Dattrino, dz. cyt., s. 29.

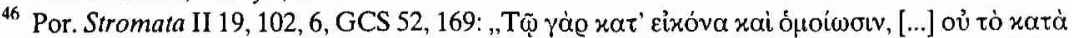

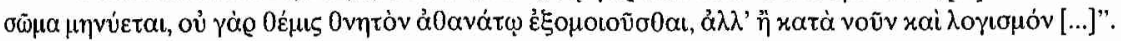


człowiek cielesny (corporeus), postępuje tak, jakby uważał, że Bóg ma ciało i postać ludzką. Sądzić w ten sposób o Bogu jest rzeczą absolutnie bezbożną",47.

Jak wynika $z$ powyższego omówienia, Orygenes w zakresie antropologii teologicznej pozostaje wierny platońskiemu dualizmowi, dla którego cialo i sfera zmysłowa są rzeczywistością jakby niższego gatunku. Obaj z Ireneuszem uznają jednak wspólne, podstawowe założenie chrześcijańskiej wiary, oddzielające zdecydowanie ich poglądy od greckiego dualizmu antropologicznego: stworzenie, odkupienie i zmartwychwstanie, mimo różnego rozłożenia akcentów co do jego części składowych i ich roli, obejmuje ostatecznie całego czlowieka.

Rozróżnienie terminów „obraz” i „podobieństwo”, zasygnalizowane w tradycji aleksandryjskiej przez Klemensa Aleksandryjskiego, zostało przez Orygenesa dokładnie skomentowane. Według autora De principiis człowiek został stworzony na obraz Boga po to, by, dzięki uczynkom, dojść do podobieństwa do Boga:

„Opisując pierwsze stworzenie człowieka, Mojżesz napisal: «I rzekł Bóg: Uczyńmy czlowieka na nasz obraz i podobieństwo» $(\operatorname{Rdz} 1,26)$ i dodal: «I stworzyl Bóg człowieka: na obraz Boga go stworzył (Rdz 1,27), stworzył go mężczyzną i kobietą, i błogosławil im» (Rdz 1, 27). Fakt, że powiedzial: Stworzyl go na obraz Boga, a przemilczal podobieństwo, dowodzi, że człowiek od momentu pierwszego stworzenia otrzymał godność obrazu, podczas gdy doskonalość podobieństwa została zarezerwowana dla niego na koniec, w tym sensie, że powinien ją zdobywać, naśladując Boga we własnym działaniu"48.

W dalszej części cytowanego tekstu Orygenes, dla ukazania różnicy i napięcia między dwoma terminami, przywołuje obok $\mathrm{Rdz} 1,26-27$ fragment $1 \mathrm{~J} 3,2$ :

„Koncepcja ta została przedstawiona w sposób jaśniejszy i wyraźniejszy przez apostoła Jana w następujących slowach: «Dzieci, nie wiemy jeszcze kim jesteśmy, ale gdy objawi się [ma na myśli Chrystusa], będziemy podobni do Niego», gdzie z pewnością wyraża [...] nadzieję upodobnienia do Boga, co zostanie udzielone przez wspaniałość zasług" ${ }^{\wedge 9}$.

${ }^{47}$ Homiliae in Genesim I 13, SCh 7bis, 56-58: „Hunc sane hominem, quem dicit ad imaginem Dei factum, non intelligimus corporalem. Non enim corporis figmentum Dei imaginem continet, neque factus esse corporalis homo dicitur, sed plasmatus [...] Is autem, qui ad imaginem Dei factus est, interior homo noster est, invisibilis et incorporalis et incorruptus atque immortalis. [...] Si qui vero hunc corporeum putet esse, qui ad imaginem et similitudinem Dei factus est, Deum ipsum corporeum et humanae formae videtur inducere; quod sentire de Deo manifestissime impium est".

${ }^{48}$ De principiis III 6, 1, SCh 268, 236: „Hoc ergo quod dixit ad imaginem Dei fecit eum et de similitudine siluit, non aliud indicat nisi quod imaginis quidem dignitatem in prima conditione percepit, similitudinis vero ei perfectio in consummatione servata est: scilicet ut ipse sibi eam propriae industriae studiis ex Dei imitatione conscisceret [...]". Orygenes wraca wielokrotnie do tej koncepcji: Contra Celsum IV 30; Homiliae in Ezechielem 13.2; Commentarium in Ioannem XX 22.

${ }^{49}$ De principiis III 6, 1, SCh 268, 236: „Per quod certissime indicat [...] similitudinem Dei sperandam, quae pro meritorum perfectione praestabitur". 
Widoczny jest w tym tekście wyraźny wpływ platońskiego Teajteta ${ }^{50}$ oraz obecność dwóch typowo orygenesowskich idei: podwójnego stworzenia oraz naśladowania Boga jako centralnego punktu życia duchowego. Oba pojęcia - obraz i podobieństwo - Orygenes odnosi do duszy ludzkiej: obraz zakorzenia ją w Bogu, podobieństwo doprowadza ją do ostatecznej doskonałości. Odwrotnie niż u Ireneusza ciało jest miejscem, w którym działa, przez które wyraża się i które pociąga ku duchowi dusza. U biskupa Lyonu ciało jest centrum ludzkiej natury, posługującym się duszą, by dojść do doskonałości i zjednoczenia z Bogiem.

Niektórzy Ojcowie z kręgu tradycji aleksandryjskiej, zarówno na Wschodzie (Atanazy, Grzegorz z Nyssy, Cyryl Aleksyndryjski), jak i na Zachodzie (Hilary, Ambroży, Mariusz Wiktoryn, Augustyn) nie odróżniają „explicite” obu terminów, wszyscy jednak podkreślają dwuznaczność, wyrażającą się w ruchu ku doskonałości, którą należy realizować. Bardziej niż o rozróżnieniu ontycznym myślą o różnicy w porządku moralnym, polegającej na dynamicznym postępie duchowym. To dynamiczne napięcie łączy obie omawiane tradycje antropologii patrystycznej. Należy jednak pamiętać, że droga rozwoju musi być rozumiana nieco inaczej, skoro wedlug Ireneusza obraz i podobieństwo dotyczą ciała, natomiast według Orygenesa - duszy, a właściwie jej wyższej części, czyli rozumu (voũs). Według Ireneusza podobieństwo Boże otrzymuje się „per Spiritum”, co sprawia, że w jego koncepcji rozróżnienie obrazu i podobieństwa nabiera cech podziału na naturę (imago in plasmate) i łaskę (similitudo per Spiritum). Według Orygenesa natomiast podobieństwo, choć jest ono darem łaski, musi być doprowadzone do doskonałości przez dobre uczynki człowieka.

W kwestii historiozbawczego aspektu obrazu i podobieństwa Orygenes, podobnie jak w całej swojej antropologii, zależny jest od platonizmu. W myśli platońskiej obraz ma charakter dynamiczny i dąży ustawicznie do odnalezienia swojego modelu i polączenia się z nim. Końcem tego procesu jest podobieństwo do Boga. Jak pisze Platon w Teajtecie:

"Upodabnianie się do Boga to stawanie się w miarę możliwości sprawiedliwym i pobożnym zgodnie $z$ mądrością"51.

Cały wysiłek w dążeniu do cnoty ma na celu zrealizowanie tego podobieństwa, które odnawia duszę $w$ jej podobieństwie do Boga. Orygenes przejmuje ten schemat, uważając, że obraz zostal dany na początku, podobieństwo zaś jest końcem życia ludzkiego:

"Czlowiek sam powinien zdobyć podobieństwo, przez własne wysiłki naśladując

Boga, aby, otrzymawszy na początku dzięki godności obrazu możliwość doskona-

\footnotetext{
${ }^{50}$ Por. Theatetus 176B.

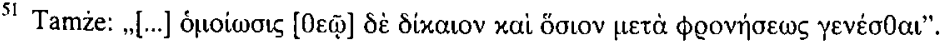


lenia, mógł ją w pełni zrealizować na końcu w doskonałym podobieństwie przez wypełnianie uczynków" 52 .

Obraz Boży w człowieku nie uległ, zdaniem Orygenesa, po grzechu Adama (niezależnie od tego, czy rozumiał go jako zdarzenie kosmiczne w preegzystencji czy też tradycyjnie, historycznie, jako czyn jednego konkretnego człowieka) utracie (intelekt i wolna wola, choć osłabione, pozostały nadal częścią natury ludzkiej), ale został poważnie zanieczyszczony (odłączenie od życia w Bogu) ${ }^{53}$. Utracony został natomiast towarzyszący obrazowi pierwotny dar nieśmiertelności i niezniszczalności, który człowiek otrzymal od Boga w akcie stworzenia i którym cieszył się w raju ${ }^{54}$. Odnowienie obrazu i dążenie do podobieństwa do Boga staje się możliwe dzięki zamieszkaniu Chrystusa - Logosu w duszy chrześcijanina. Według Orygenesa, posługującego się obrazem zaczerpniętym z przypowieści o siewcy, czlowiek, który otrzymał od Logosu nasienie (semen) Boga, staje się synem Boga, gdy nasienie to zaczyna w nim wzrastać i gdy Chrystus kształtuje się w Jego duszy, np. podczas słuchania słowa Bożego ${ }^{55}$. Tak więc dusza, która przez chrzest zostaje oczyszczona z grzechów i powraca do przejrzystości obrazu, powinna następnie przez naśladowanie Chrystusa, czyli przez praktykę cnót, wzrastać aż do uzyskania podobieństwa do Niego.

Może budzić zdziwienie nacisk, jaki Orygenes kładzie na rolę wysiłku moralnego i wolnej woli w tym procesie. Trzeba jednak pamiętać, że była to reakcja na gnostycki fatalizm i nie należy zbyt pochopnie doszukiwać się w postawie Aleksandryjczyka zapowiedzi semipelagianizmu. W rzeczywistości, gdy porówna się różne teksty Orygenesa, okazuje się, że przy wymaganiu od czlowieka poważnego wysiłku osobistego, nie zapomina on, że to od samego Boga pochodzi udział człowieka w Jego naturze, i tym samym zbliża się do nauczania Ireneusza ${ }^{56}$. Świadczy o tym następujący tekst Orygenesa:

„Jeżeli jest Duch miłości i Syn miłości, i jeżeli Bóg jest miłościa, jest rzeczą pewna, że z jedynego źródła boskiego ojcostwa wychodzą Syn i Duch, i że z ich obfitości

${ }^{52}$ De principiis III 6, 1, SCh 268, 236: „[...] ut ipse sibi eam propriae industriae studiis ex Dei imitatione conscisceret [...], quo possibilitatem sibi perfectionis in initis datam per imaginis dignitatem, in fine demum per operum expletionem perfectam sibi ipse similitudinem consummaret".

53 Por. Homiliae in Genesim IX 2, SCh 7bis, 242-246; Commentarium in Romanos II 5, PG 14, $882 \mathrm{~A}$; zob. J. Laporte, Théologie liturgique de Philon d'Aléxandrie et d'Origène, Paris 1995, 156.

${ }^{54}$ Por. Origenes, Commentarium in Romanos X 14, PG 14, 1275A: „Debitores enim effecti sumus secundum illum qui primitus acceptum immortalitatis et incorruptibilitatis censum in paradiso perdidit persuasione serpentis; et ideo debitores efficimur omnes quotquot in similitudinem Adae sorte praevaricationis astringimur".

${ }_{55}$ Por. Homiliae in Leviticum XII 7, SCh 287, 192-194: „[...] ex isto semine verbi Dei, quod seminatur, Christus nascitur in corde auditorum [...]".

56 Cechą wschodniej teologii patrystycznej, zwłaszcza tradycji aleksandryjskiej, było nie stawianie ścisłej granicy między tym, co należy do porządku natury $i$ łaski, ale raczej uznawanie ścislej wspólpracy natury z laską (synergizm) czy wręcz przekonanie, że również natura jest laską, ponieważ pochodzi od Stwórcy. 
obfitość miłości przelewa się w serca świętych, aby udzielić im uczestnictwa w naturze boskiej, zgodnie z nauczaniem apostoła Pawła"57.

Tak więc, zdaniem Orygenesa, podobnie jak u Ireneusza, to Boski Logos i Duch Święty, który w Nim działa, formują wiernego i formują się w nim. $\mathrm{H}$. Crouzel celnie charakteryzuje poszczególne elementy procesu wzrostu duchowego w ujęciu Aleksandryjczyka:

„Naśladowanie Jezusa kładzie akcent na nasz wysiłek osobisty; działanie Chrystusa formujące wiernych, formujące Jego samego $w$ nich - na rolę łaski; koncepcja cnoty jako uczestnictwa w Chrystusie, który jest każdą cnotą, oraz jako narodzenia Słowa w sercu wierzącego ukazuje aspekt rzeczywiście fizyczny i egzystencjalny postępu duchowego, który czyni $z$ nas nowe byty, dając nam nową naturę̧"s8.

Należy jeszcze zwrócić uwagę na dwie istotne sprawy w nauce Orygenesa. Po pierwsze, aby naśladować Chrystusa i doznać przemiany w Nim, trzeba Go kontemplować:

„Miejmy więc zawsze oczy utkwione w tym obrazie Boga, żebyśmy mogli być na nowo uksztaltowani na Jego podobieństwo",59.

Pobrzmiewają tu reminiscencje platońskiej kontemplacji ubóstwiającej, ale także wyraźny wpływ św. Pawła (2 Kor 3,18$)$. Odkryte oblicze, oglądające

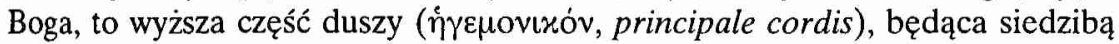
obrazu Boga. Odkrycie jej polega na oczyszczeniu z dóbr ziemskich, cielesnych przywiązań i materialnych obrazów, a także z powierzchownej, literalnej interpretacji Pisma świętego i prowadzi do duchowego poznania Chrystusa, a tym samym do upodobnienia się do Niego.

Po drugie, według Orygenesa, podobnie jak u Ireneusza, podobieństwo do Boga ma wyraźny sens eschatologiczny. Pełne upodobnienie się do chwalebnego obrazu Chrystusa zrealizuje się dopiero po zmartwychwstaniu. Chrzest, nazywany przez Aleksandryjczyka pierwszym (sakramentalnym) zmartwychwstaniem inauguruje w nas podobieństwo do Boga i jest tylko punktem wyjścia we wspinaczce duchowej. Dopiero drugie zmartwychwstanie przekształci nasze

${ }^{57}$ Commentarium in Romanos IV 9, PG 14, 997BC: „Quod si et Spiritus charitatis, et Filius charitatis, et Deus charitas invenitur, certum est quod ex uno Paternae Deitatis fonte et Filius intelligendus est, et Spiritus sanctus, ex cuius abundantia etiam sanctorum cordibus ad participationem capiendam divinae naturae, sicut Petrus apostolus edocuit, abundantia charitatis infunditur"; zob. M. Szram, Nauka o grzechu Adama w „Komentarzu do Listu św. Pawta do Rzymian" Orygenesa, w: Grzech pierworodny. Augustyn, Dzieje procesu Pelagiusza, red. H. Pietras, ZMT 12, Kraków 1999, 51-56.

${ }^{58}$ H. Crouzel, Théologie de l'image de Dieu chez Origène, Paris 1956, 232.

${ }^{59}$ Homiliae in Genesim I 13, 85-86, SCh 7bis, 62: „Semper ergo intueamur istam imaginem Dei, ut possimus ad eius similitudinem reformari". 
nędzne ciała w ciała chwały na podobieństwo zmartwychwstałego Chrystusa (Flp 3,21), uczyni ludzi podobnymi do Logosu i pozwoli ludziom oglądać Boga takim, jakim jest ${ }^{60}$.

Wyczerpujące przedstawienie skomplikowanego tematu obrazu i podobieństwa do Boga w antropologii teologicznej Ireneusza i Orygenesa przerasta ramy niniejszego artykułu. Zostały tu pominięte takie zagadnienia $\mathrm{z}$ nim związane, jak: trynitarny wymiar obrazu Bożego w czlowieku (charakterystyczny dla późniejszej patrystyki); stosunek obrazu do podobieństwa a relacja natury do łaski; szczególowa rola Syna Bożego, Ducha Świętego i człowieka w realizacji obrazu i podobieństwa. W podsumowaniu chciałbym raz jeszcze przypomnieć, w czym poglądy obu teologów są zbieżne, w czym się różnią, oraz zasygnalizować, w jaki sposób oddziałały one na późniejszą teologię.

Ireneusz i Orygenes są zgodni co do fundamentalnych zalożeń antropologii teologicznej. Opierają ją na tekście biblijnym Rdz 1, 26-27 w thumaczeniu Septuaginty, odróżniając znaczeniowo pojęcia „obrazu” i „podobieństwa”. Znaczenie obrazu jest zdecydowanie chrystologiczne: tylko dzięki Chrystuso. wi - obrazowi Boga we właściwym tego słowa znaczeniu - człowiek poznaje swoją tajemnicę, rozpoznaje swoją godność, doskonali się i dąży do upodobnienia do Boga. Obraz ma charakter bardziej statyczny i jest związany z porządkiem ontycznym, podobieństwo natomiast lączy się z działaniem, rozwojem, procesem, i należy bardziej do porządku moralno-duchowego. Stany wy. rażane przez oba pojęcia ulegają na przestrzeni historii zbawienia różnym zmianom: osłabieniu bądź zanikowi po grzechu pierworodnym, odnowienir przez inkarnację Logosu i przez chrzest w życiu pojedynczych chrześcijan ostatecznemu wypełnieniu i osiągnięciu stanu doskonałości w czasach eschato logicznych. Nauka patrystyczna na temat obrazu i podobieństwa jest ściśl uzależniona od polemiki z błędnowiercami, w wypadku naszych autorów zwłaszcza od dyskusji z gnostykami.

Poglądy Ireneusza i Orygenesa różnią się jednak w istotnych szczegółach związanych ze znaczeniem terminów „obraz" i ,podobieństwo", i wynikającycl z określonego dziedzictwa kulturowego:

1) Ireneusz jako przedstawiciel tradycji azjatyckiej podkreślał przeciv gnostykom nadrzędny charakter ciala w strukturze czlowieka, i w ciele stwo rzonym na wzór ciała Chrystusa dostrzegal istotny element obrazu Bog: w człowieku. Orygenes jako reprezentant tradycji aleksandryjskiej był wiern platońskiemu spirytualizmowi i uważał, że obraz duchowego Boga musi być te

${ }^{60}$ Por. Homiliae in Genesim I 13, SCh 7bis, 58; zob. też Commentarium in Matthaeum XIII 2 Commentarium in Romanos VII 4. 
duchowy, a więc mieścić się w duszy, a nie w ciele, które musi być poddane uduchowieniu.

2) Ireneusz, mimo akcentowania cielesności w koncepcji człowieka bliższy był całościowemu ujmowaniu Osoby ludzkiej, zlożonej z ciała, duszy i Ducha Świętego. Orygenes, mimo uznawania trójpodziału - duch, dusza, ciało w antropologii skupiał się na duszy.

3) Według Ireneusza obraz Boga w człowieku był do momentu wcielenia Chrystusa nieuświadomiony, a podobieństwo - zostało utracone na skutek pierwszego grzechu i stopniowo rozwija się w człowieku od momentu chrztu świętego. Według Orygenesa obraz Boga został zatarty, lecz nie utracony. Przywraca go chrzest święty, na którym człowiek otrzymuje również zadatek podobieństwa, który musi rozwijać.

4) Ireneusz widział w podobieństwie przede wszystkim dzieło Ducha Świętego, który jest jego właściwym podmiotem. Orygenes, mimo, iż podkreślał, że podobieństwo realizuje się przez zamieszkanie Chrystusa i Jego Ducha w człowieku, mówił o nim przede wszystkim jako o efekcie osobistych wysitków czlowieka.

5) Ireneusz zdawał się utożsamiać obraz $z$ naturą, a podobieństwo $z$ laską w człowieku, Orygenes raczej uznawal przenikanie się tego, co naturalne z tym, co nadnaturalne, zarówno w obrazie, jak i w podobieństwie.

Jeśli chodzi o wpływ obu tradycji na przyszłą teologię, wydaje się, że w okresie patrystycznym i średniowiecznym większą popularnością cieszyło się ujęcie aleksandryjskie, akcentujące naczelną rolę duszy w czlowieku. $\mathrm{Z}$ drugiej strony nie należy zapominać, że rozwiązanie azjatyckie, reprezentowane glównie przez Ireneusza, może wprawdzie budzić podejrzenie o skrajny materializm, zwłaszcza gdy pozbawi się je kontekstu, w którym powstało, jednak bliższe jest biblijnej koncepcji człowieka i to ono bardziej odpowiada współczesnej antropologii teologicznej.

\author{
DE L'IMAGE À LA RESSEMBLANCE DE DIEU. \\ LA CONCEPTION DYNAMIQUE DE L'ANTHROPOLOGIE \\ THÉOLOGIQUE AUX II ${ }^{\mathrm{e}}$ ET III ${ }^{\mathrm{e}}$ SIÈCLES \\ (LE POINT DE VUE D'IRÉNÉE ET D'ORIGÈNE)
}

(Resumé)

L'article présente les questions fondamentales de l'anthropologie patristique aux II $^{\mathrm{e}}$ et III ${ }^{\mathrm{e}}$ siècles: les traits caractéristiques des notions de l'image de Dieu et de la ressemblance de Dieu, et la relation entre elles. L'auteur compare deux écrivains majeurs de cette période: Irénée, lié avec la tradition asiatique (plus 
„matérialiste”) et Origène, représentant de la tradition alexandrine (plus „spirituelle"). Dans leur doctrines il y a quelques éléments presque identiques: le sens christologique de l'image (c'est le Christ qui est vraie et première image de Dieu); la différence sémentique entre notions de l'image et de la ressemblance; le caractère statique et ontique de l'image, et active et moral de la ressemblance. Mais malgré ces points communs, Irénée et Origène comprennent autrement ces deux notions et en conséquence leur doctrines anthropologiques sont différentes.

Irénée souligne contre les gnostiques la position supérieure du corps dans la structure de l'homme et situe l'element essentiel de l'image de Dieu dans le corps créé à l'exemple du corps du Christ. Selon l'évêque de Lyon l'image de Dieu n'était pas reconnue par les hommes jusqu'à l'incarnation du Christ. La ressemblance était perdue après le péché des premiers hommes et se développe dans l'homme à peine depuis le baptême. Selon Irénée, c'est l'Esprit Saint qui est createur et personnification de la ressemblance de Dieu. L'auteur d'Adversus haereses semble identifier l'image avec la nature et la ressemblance avec la grâce.

Origène est fidèle au spiritualisme platonien et place l'image de Dieu, qui est Esprit, dans l'âme humaine, pas dans le corps. Selon théologien alexandrin l'image de Dieu après le premier péché n'était pas perdue, mais seulement affaibli. C'est le baptême qui la renouvele. C'est aussi pendant ce premier sacrement que l'homme reçoit la semence de la ressemblance pour la développer. Selon Origène, la ressemblance de Dieu signifie la présence perpétuelle du Christ et de l'Esprit dans l'homme, mais on atteind cet état surtout par ses propres efforts. Dans l'image autant que dans la ressemblance il y a les éléments naturels et surnaturels qui se pénétrent réciproquement.

Quand il s'agit de l'influence de deux traditions sur la théologie ultérieure, il semble que c'était le point de vue d'Origène, posant l'accent à la rôle fondamentale de l'âme dans l'homme, qui a gagné le plus grand succès au Moyen Âge. Mais l'opinion d'Irénée, malgré son „matérialisme" antignostique, semble être plus proche de la conception intégrale de l'homme dans la Bible et, en conséquence, elle correspond mieux à l'anthropologie théologique contemporaine. 